\title{
Contemporary Ottoman Views of Catherine the Great
}

DOI:

10.1111/1754-0208.12591

\section{Document Version}

Accepted author manuscript

Link to publication record in Manchester Research Explorer

\section{Citation for published version (APA):}

Menchinger, E. (2019). Contemporary Ottoman Views of Catherine the Great. Journal for Eighteenth-Century Studies, 42(1), 84-100. https://doi.org/10.1111/1754-0208.12591

\section{Published in:}

Journal for Eighteenth-Century Studies

\section{Citing this paper}

Please note that where the full-text provided on Manchester Research Explorer is the Author Accepted Manuscript or Proof version this may differ from the final Published version. If citing, it is advised that you check and use the publisher's definitive version.

\section{General rights}

Copyright and moral rights for the publications made accessible in the Research Explorer are retained by the authors and/or other copyright owners and it is a condition of accessing publications that users recognise and abide by the legal requirements associated with these rights.

\section{Takedown policy}

If you believe that this document breaches copyright please refer to the University of Manchester's Takedown Procedures [http://man.ac.uk/04Y6Bo] or contact uml.scholarlycommunications@manchester.ac.uk providing relevant details, so we can investigate your claim.

\section{OPEN ACCESS}


"Contemporary Ottoman Views of Catherine the Great"

Russia's southward expansion to the Black Sea unleashed one of the great geopolitical struggles of eighteenth-century Europe. By the reign of Peter I (Petro Alekseievich, d. 1725), the once farflung realm of the "Muscovite" (Moskov diyârı) reached the Ottoman Empire's borders and lands for centuries dominated by Muslim Turks and Tatars. Between 1683 and 1812, the Ottoman and Russian empires fought no fewer than six wars. For Ottoman rulers, Russia’s rapid rise to power in the north evoked surprise, envy, and acute anxiety. It is true to say that eighteenth-century Ottomans saw Russia as their great political rival, yet it is also true that they were increasingly unequal to the competition. ${ }^{1}$

One of the key figures in this struggle was Catherine "the Great," born Sophie Friederike Auguste of Anhalt-Zerbst, empress of Russia from 1762 to 1796. Under Catherine, the Russians defeated Ottoman forces in two wars (1768-74 and 1787-92), annexed the Crimea (1783), and at last established themselves permanently in warm-water ports on the Black Sea. ${ }^{2}$ Ottomans of the

1 See Virginia Aksan, Ottoman Wars, 1700-1870: an Empire Besieged (New York: Routledge Press, 2007); and Brian Davies, Empire and Military Revolution in Eastern Europe: Russia’s Turkish Wars in the Eighteenth Century (London: Continuum, 2011).

2 See Alan W. Fisher's classic study The Russian Annexation of the Crimea, 1772-1783 (Cambridge: Cambridge Univ. Press, 1970). Also, Brian Davies, The Russo-Turkish War, 1768-1774: Catherine II and the Ottoman Empire (London: Bloomsbury Academic, 2016); and Isabel de Madariaga, Russia in the Age of Catherine the Great (New Haven: Yale Univ. Press, 1981). 
time not surprisingly reviled Catherine. For them, more than any other tsar or tsarina, she embodied Russian aggression and hostility. This article explores these views in a number of late eighteenth-century Ottoman writings, including chronicles, embassy reports, and captivity narratives. Shaped in part by misogyny, in part by political animus, Ottoman accounts struggle to make sense of the empress. Their depictions are extremely hostile but also, for lack of a better word, fascinated by her. Catherine was at once a usurper and foreigner, a possible regicide, and a sovereign female ruler - a concept utterly foreign to Ottoman observers - but she was also highly successful. Indeed, it was this success and how to explain it that most taxed Ottoman contemporaries. Catherine was, many agreed, no less than a force of nature or trial sent by God.

\section{Catherine in Chronicles and Travel Reports}

Ottoman accounts of Catherine, while more numerous than for earlier Russian rulers, are fairly rare in view of Russia's long political shadow. Whether from disinterest, chauvinism, or cultural reticence about "infidels," it was typical of early modern Ottoman scribes to pass over nonMuslim rulers and countries mostly unremarked in their writings. Waning Ottoman military power began to change this situation by the early eighteenth century, forcing diplomatic engagement with neighbors and a heightened awareness of the outside world, but references to Europe and its inhabitants often remained cursory. ${ }^{3}$ Like other foreign rulers, contemporary Ottoman sources mostly note Catherine by title rather than name. She is called the Russian or

3 Bernard Lewis, The Muslim Discovery of Europe (New York: W.W. Norton, 1982). See also Virginia Aksan, "Ottoman Sources of Information on Europe in the Eighteenth-Century," Archivum Ottomanicum 11 (1986 [1988]): 5-16. 
Muscovite "queen (kraliçe)," "tsarina (çariçe)," "empress (imparatoriçe)," or more rarely "autocratix (oftokratoriçe) ${ }^{4}$ Where sources expand further, though, we see that Ottomans not only knew more than they led on but had strong views about the empress.

Where could contemporary Ottomans glean information on Catherine? We can presume that a good deal reached the empire through translations, for one, both from official Russian documents as well as from more mundane sources like newspapers, or "gâzetâ" as one source calls them, "a word for printed papers of events which arrive from time to time." Sultan Abdülhamid I (1774-89) founded a newspaper translation office circa 1780, though earlier translation seems to have been ad hoc. The Ottoman vassal princes (voyvodas) of Moldavia and Wallachia also sent reports to Istanbul that periodically contained news from Russia, while more information came through word of mouth, either from diplomatic circles in the capital or from Ottomans who visited Russia as travelers, captives, and envoys. ${ }^{6}$ Sources reached even to

4 E.g. Mustafa Kesbî, İbretnümâ-yı Devlet: Tahlil ve Tenkitli Metin (Ankara: Türk Tarih Kurumu, 2002), 386, 390, 403; Ahmed Câvid, Osmanl1-Rus İlișkileri Tarihi: Ahmed Câvid Bey’in Müntehabâtı, ed. Adnan Baycar (Istanbul: Yeditepe, 2004), 387, 399, 423, 553; and

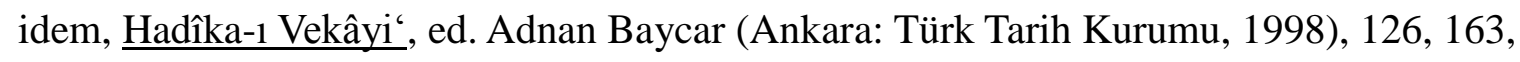
$166,170$.

5 Quoted in Aksan, "Sources," 11. For a report of Emel'ian Pugachev's death translated from "a proclamation by the Russian empress," see Muharrem Saffet Çalışkan, ed., "(Vekâyi'nüvis) Enverî Sadullah Efendi ve Tarihinin I. Cildi’nin Metin ve Tahlili (1182-1188 / 1768-1774)” (Ph.D. diss., Marmara Univ., 2000), 457.

6 One chronicler (Çalışkan, 457) writes that the voyvodas had an established duty to supply 
biographies of the empress, first appearing shortly after her death in the Turkish adaptation of Jean-Henri Castéra’s Vie de Catherine II, impératrice de Russie. Suffice it to say, though, the quality of this information proved uneven. ${ }^{7}$

Court histories give some of our earliest references to Catherine. The Ottoman court historian (vekâyi'nüvis) recorded the dynasty’s history as a salaried official, using an annal form and privileged access to state archives and focusing largely on the empire's internal affairs. Some who staffed this post in the late 1700s mentioned the empress, however. One such reference comes from Sadullah Enverî (d. 1793), who served as court historian for five terms starting in 1768 and who briefly recounts her background. "Rusya imparatoriçesi olan Katarina fi'l-asl Rusya imparatoru olan zevcini hal' eyledikde,” he writes, “imparatorluk oğlı Granduka nâm foreign intelligence. The French ambassador Vergennes related a 1764 conversation with an Ottoman minister who was well-informed of Russian involvement in Poland and the murder of Ivan VI, which he predicted would be Catherine's downfall. See Aksan, "Sources of Information," 11-12, and L. Bonneville de Marsangy, Le chevalier de Vergennes, son ambassade à Constantinople (Paris: E. Plon, 1894), 2: 284-85. Mehmed Emnî witnessed the 1741 palace coup in St. Petersburg and supplied information based on oral and written accounts: Mehmed Emnî Beyefendi (Pașa)'nin Rusya Sefâreti ve Sefâret-nâmesi, ed. Münir Aktepe (Ankara: Türk Tarih Kurumu, 1974), 72.

7 This work was translated by a Greek dragoman, Yakovaki Argyropoulos (d. 1850): Moskov diyârında mukîm bulunan Kasterâ nâm. . .(Cairo: Bulak, 1828/30); and Franz Babinger, Die Geschichtsschreiber der Osmanen und ihre Werke (Leipzig: O. Hassarowitz, 1927), 310 n. 1. Aksan has found ("Sources," 11 n. 26) manuscripts of this work from as early as 1800. 
gulâmın hakk-1 sarîhi iken sabîdür deyu imparatorluğun fuzûli zabt ve kendü kendüsine Rusya imparatoriçesi olduğundan. ..” [When the Russian empress Catherine deposed her husband, the true Russian emperor, she seized the imperium and became Russian empress herself even though her son the Grand Duke had the clear right, saying he was only a child.] Enverî adds that Catherine also despoiled church properties and oppressed her subjects through confiscations and needless wars. ${ }^{8}$

Enverî’s successor, Halil Nûrî (d. 1799), court historian from 1794 until his death, included a notice on Catherine's death in his own work. Nûrî records how news of the empress' death reached Istanbul and adds this hostile coda:

Mürd olan mesfûrenin sinni altmış yedi ve müddet-i krallığı otuz dört seneye bâliğ olmuşdur bi-hikmeti'llâhi te'âlâ tâli'i kavî bir habîse olmağla iki def'a zuhûr iden seferlerde kendüden bir vechle ahz-1 sâr u intikâm mümkün olamayub lâkin biirâdeti’llâhi te‘âlâ bu def'a sâha-i 'âlemden vücûd-ı habâset ref' ü izâle ve mücâzât-1 ef'âl-1 şeni'ası uhde-i zebâniyâna ihâle kılınmağla. . .

The late [empress] was sixty-seven years old and reigned thirty-four years. She was a vile but fortunate woman, by God's wisdom, so we failed utterly to take our revenge on her in two wars. Now, though, by God's will, her evil body has been wiped from the world and

8 Çalışkan, 456. On Enverî and his work, see Türkiye Diyanet Vakfı İslâm Ansiklopedisi (TDV), (Üsküdar, 1988-. 40 vols.), s.v. "Enverî, Sadullah"; and Babinger, 320-22. His predecessor Hâkim Mehmed (d. 1770) passes over the palace coup entirely: Târih, MS Bağdat nr. 233, fols. 185b-86a, Topkap1 Palace Museum Library. 
punishment of her wicked deeds is given over to the demons of hell. ${ }^{9}$

Even more hostile is the view of Ahmed Vâsıf (d. 1806), court historian on and off from 1783 to 1805 . Vâsıf's past colored his opinions, to be sure. The historian not only fought in the Russian-Ottoman wars of the late century but was also held captive in St. Petersburg; he seems to have learned some Russian and later served as a negotiator with Russian authorities. He may even have met Catherine, who released him from captivity in 1772 to carry peace proposals to Ottoman lines. Vâsif digressed on the empress several times in his chronicle, mentioning her for the first time, like Halil Nûrî, in a death notice. In a passage entitled "Helâk-1 kraliçe-i Moskov [The Death of the Muscovite Queen]," he writes that Catherine had come to power as an outsider, a German, and that she killed her husband the emperor with the help of Russian nobles and "seized control of Muscovy by force (kendüsi tagallüben Moskov memâlikini istimlâk)." Vâsıf tells us clearly what he thinks of Catherine's fate: "Katerina nâm pîre-zen bu esnâda hâviye-i dûzahı mesken eyleyüb..." [The old hag named Catherine now resides in the lowest pit of hell. $]^{10}$

Vâsıf seems to have known all about Catherine's dubious origins. He treated her 1762 palace coup in relation to one Mehmed Derviş, who went to Russia as ambassador in the year

9 Nurî, Târih, MS V3369, fols. 257a-57b, Beyazıt State Library. On Nurî, TDV, s.v. "Halil Nurî”; and Babinger, 323.

10 Vâsıf, Mehâsinü'l-Âsâr ve Hakâîkü'l-Ahbâr, MS nr. 5979, fols. 146b-47a, Istanbul Univ. Library. On Vâsıf's life and work, see Ethan L. Menchinger, The First of the Modern Ottomans: the Intellectual History of Ahmed Vâsıf (Cambridge: Cambridge Univ. Press, 2017). 
1764. Vâsıf writes as follows:

Nemçe herseklerinden birinin duhteri olan Katerina Moskov imparatoruna varub kefere memleketlerinde nisvânın zükûre galebesi emr-i tabî‘i olduğuna binâ‘en giderek mesfûrede nüfûz hâsıl ve imparatora galebesi derece-i kemâle vâsıl olub bu mahkûmiyeti mutlaka i'tibârını selb ve zevcesi mesfûreye îcâb-1 kuvve-i kalb idüb imparatorluk buhârı dimağına su'ûd ve Moskovlu'yı zevcinden tebrîd ü tevhîş ile izhâr-1 hukûd idüb Moskovlu'nın rü'esâ-yı 'askerîsi merkûmeye pâbeste-i meyl ü tevâd ve ba'zı 'uhûd ile zevcini i‘dâm ve kendüsini imparator itmeğe safkazen-i ittihâd olmalarıyla yine hemhâki olanlardan Orloflar cümleden evvel nâr-1 fitneyi işgâl ve imparatorı i‘dâm ü istîsâl ve mesfûreyi imparatorluk mastabasına ik'âd ile fi'l-hâl def'-i şûriş ü ihtilâl eyledikleri. . .

Catherine, daughter of one of the German dukes, married the Muscovite emperor. Since in infidel lands women naturally prevail over men, she in time gained influence and came to dominate the emperor. This utter subjection robbed him of respect and emboldened his wife; the vapors of the imperium went to her head. [Catherine] showed malice and turned the Muscovites against her husband, while the heads of the Russian army inclined to her. They plotted by certain oaths to kill her husband and make her empress. Led above all by the Orlov brothers, they then rebelled, killed the emperor, enthroned her as empress, and immediately ended the uprising.

Vâsıf writes that reports of this event reached Istanbul, upon which the sultan sent Mehmed Derviş to St. Petersburg. ${ }^{11}$

11 Vâsıf, Mehâsinü'l-Âsâr ve Hakâîü'l-Ahbâr (Istanbul: Darüttıbaati'l-Âmire, 1804), 1: 238. 
Vâsif adds to this detail elsewhere, focusing again on the coup that brought Catherine to power. In an entry for the year 1774 , he writes that the Russian empress Catherine was originally German. She married the Russian emperor and conceived a desire to seize power (hevâ-y1 zabt-1 mülk derûnunda cevelân). Catherine then took the Orlovs into her confidence and secured their allegiance, explaining that, when she had control, she would share governance and even ennoble them. Once the Orlov brothers had enough support, they put their plot into action and murdered the emperor. ${ }^{12}$ Vâsıf next turns to the issue of Catherine's son, the heir and future Paul I (Pavel Petrovich, d. 1801). Paul was a child, says Vâsıf. His "ill-starred mother (mâder-i bed-ahteri olan Katerina)" first became regent but, after only a few days, usurped the imperial throne. Catherine rewarded her followers and the Orlovs richly. As for Paul, Vâsıf alleges that she placed him under tutors who deliberately corrupted the young man: "Hadd-i bülûga resîde oldukda," he writes,

Müsta ‘iddân-1 hevâ vü hevese 'illet-i iftinân olan duhterân-1 sîmber ve kenîzegân-1 sanem-peykeri üzerine teslît ile meşk-i 'aşk ve ta'lîm-i fısk itdirerek hevâsını o tarafa munsarif ve kendüsi kayd-1 hayât ile bi'l-istiklâl imparatorluğa mutasarrıf olub

When he reached puberty, [Catherine] had [Paul] initiated into sin and given lessons in passion, letting silver-bosomed young women and lovely seductresses have their way with him. She diverted his interest in this wise and so ruled as empress, independently, for life. ${ }^{13}$

12 Vâsıf (1804), 2: 287.

13 Ibid, 2: 287-88. 
These passages call attention to some key points. The first is nearly too obvious for comment: Catherine was a woman. The use of feminine verbal forms surely jarred for Ottomans, for whom women had little if any formal place in politics or public affairs. Ottoman royal women, it is true, played important roles and at times directly wielded power as consorts, mothers, and princesses. This was especially so during the sixteenth and seventeenth centuries under a series of formidable royal mothers (vâlide sultân), who acted as de facto regents, directed foreign diplomacy, and controlled political factions. Female power was a reality in the empire but neither institutionalized nor uncontroversial. While such women used many of the same levers as men, relying on patronage and personal networks to act inside and outside the palace, they often did so against perceptions that their power was illegitimate or even a force of moral and institutional corruption—a so-called "sultanate of women." Unlike Europe, then, where queens and empresses reigned and at times ruled, Ottoman society had no real experience with institutionalized, sovereign female rule. Strictly speaking, there were no Ottoman "queens."14 Second, the passages undermine Catherine's legitimacy in various ways. They depict her, with reasonable accuracy, as a usurper who not only deposed her husband but passed over her son, the heir, to rule in her own right; Enverî and Vâsif are clear on this point. The passages strongly suggest that Catherine was likewise responsible for her husband's death at the hands of the

14 See Leslie Peirce, The Imperial Harem: Women and Sovereignty in the Ottoman Empire (New York: Oxford Univ. Press, 1993); and idem, "Beyond Harem Walls: Ottoman Royal Women and the Exercise of Power," in Servants of the Dynasty: Palace Women in World History, ed. Anne Walthall (Berkeley, 2008), 81-95. Islamic history as a whole contains almost no examples of sovereign female rulers. 
Orlovs - that she was both a usurper and a regicide.

It is easy for us to see an undercurrent of misogyny in these sources. Certainly, Catherine's sex was one source of their hostility. Vâsıf himself resorts to gendered, disparaging language, claims baselessly that the empress morally and sexually corrupted her son, and studs his narrative with words that can be read in multiple ways, perhaps as sexual double entendre. ${ }^{15}$ It is quite possible that he had heard rumors about Catherine's sexual habits. In another way, though, Vâsıf simply reflects commonly-held views in early modern Ottoman society. The moral literature of the day pigeonholed women as weaker, less able, and less intelligent than men, but also shrewd, scheming, capricious, and more given to vice. They were considered sexually irrepressible - their unbridled desire was perilous, even a threat to social order. Women needed to be under the close supervision of men, it followed. The popular sixteenth-century preacher Birgivî Mehmed (d. 1573) wrote that a woman's duty was at home - to bake bread, clean dishes, do the wash, prepare meals, and be obedient to male relatives - and any failure to do so was sinful. Works of "practical philosophy," based on the ethical tradition of Aristotle and his commentators, also described an ideal and orderly household in chapters on home economics (tedbîr-i menzil or oikonomia), always with males dominant and females subordinate. A female ruler, then, was not just an oddity but something more disquieting. As the head of the realm, the dynastic household writ large, she completely overturned Ottoman ideas of proper social and

15 E.g., Așinâ itmek: to confide in or make an intimate acquaintance. Enbâz olmak: to become a partner, mate, or companion. Hemrâz itmek: to take in confidence or make someone an intimate or bosom friend. 
political order. She was unnatural and threatening. ${ }^{16}$

In these views, moreover, Ottomans did not differ so markedly from their counterparts in Europe or Russia itself. Western observers often noted Catherine's supposedly feminine weaknesses such as vanity, caprice, and voluptuousness. The British press attacked her in misogynistic and at times sexually explicit caricatures, where Catherine appears as deviant and insatiable, while even the empress' admirer Voltaire "took delight in the fact that the Moslem Turks were being humiliated by a woman." ${ }^{17}$ In Russia, critics proved more muted but were still present. N. M. Karamzin, for instance, used Catherine in his nineteenth-century history to illustrate the idea that "women are more prone to despotism than men." "And as far as she is concerned," he wrote, "it can justly be averred that she is in this particular a woman among women.",18

16 See Madeline Zilfi, "Women in the Ottoman Empire," in The Cambridge History of Turkey (Cambridge: Cambridge Univ. Press, 2013), 3: 226-55. The classic Ottoman work of practical philosophy was Kınâlızâde's Ahlâk-1 Alâ'î (Istanbul: Klasik, 2007).

17 Brenda Meehan-Waters, "Catherine the Great and the Problem of Female Rule," Russian Review 34 (1975): 294. In one famous 1791 cartoon, “An Imperial Stride!” Catherine straddles the Russian and Ottoman empires above the crowned heads of Europe, who look up her petticoats and make quips like, "The whole Turkish army wouldn’t satisfy her!"

18 Meehan-Waters, 295, who argues that domestic criticism generally focused less on Catherine's sex. A recent book ties the acceptance of female rule in eighteenth-century Russia to the popularity of the cult of St. Catherine of Alexandria: Gary Marker, Imperial Saint: the Cult of St. Catherine and the Dawn of Female Rule in Russia (DeKalb, IL, 2007). 
Another Ottoman who fixated on sex was Ahmed Resmî (d. 1783), an ambassador and historian. Resmî discussed the empress in a short history the 1768-74 war with a view less openly hostile than Vâsıf's. For Resmî, her rule was more a point of novelty. "For a time the ruling Tsarinas were female," he writes. "Since Frankish people [i.e. Europeans] are immoderate in affection for their women, believing in extreme obedience to this Tsarina, Catherine, and in the saintly intercession of the Virgin Mary, officials and able men flocked to her presence from other nations."

Filled with love for the Tsarina, they clambered and clamored to sacrifice life and limb for her sake. The Tsarina, moreover, was a sharper who from the lately deceased Austrian empress Maria Theresa had learned graces with which to charm such men. She was more openhearted than her predecessor to close dignitaries and officers, caressing and cosseting them. . 19

Like Vâsıf, Resmî credited Catherine's power in part to her exploitation of male weakness - namely, the weakness of European men for their women. This was an emasculating loss of control for Ottomans. They therefore puzzled over European notions of gallantry, considering them as ways in which women manipulated men into doing their will. Resmî himself recalls how, as an envoy to the Habsburg Empire, he once met a youth who had kissed the hands of Maria Theresa's daughters and was thus ready to give his life in battle. "Frankish people are

19 Resmî, A Summary of Admonitions: a Chronicle of the 1768-1774 Russian-Ottoman War, trans. Ethan L. Menchinger (Istanbul: Isis Press, 2011), 83. On Resmî himself, see Virginia Aksan, An Ottoman Statesman in War and Peace: Ahmed Resmi Efendi, 1700-1783 (Leiden: Brill, 1995). 
carried to transport by a woman's favor," Resmî says.

You see, to allow one to kiss the hand is a great honor and kindness in the opinion of Frankish peoples. And if it is of the female sex, if her glove is removed and she will let him kiss her bare hand, it is, being reckoned very great fortune, a means to make him leap trenches or career down precipices. ${ }^{20}$

Resmî's implication is not kind to Catherine, of course. She has manipulated and flattered her subjects into loyalty; she has made men into dupes and cuckolds.

More sources for Catherine come to us from the reports of men who traveled in person to Russia, either as envoys or captives. The Ottoman Empire did not keep permanent embassies abroad until the late eighteenth-century, sending ambassadors only on special occasions like the signing of a treaty or a new ruler's accession. These envoys wrote reports (sefâretnâme) on their return for court consumption, usually describing their itinerary, ceremonies, and the host country's manners, government, and political affairs. ${ }^{21}$ Several Ottoman envoys visited Russia under Catherine. We know that the empress herself requested a visit in 1764. The report of this ambassador, Mehmed Derviş, may well have discussed the palace coup that brought Catherine to power, as well as her role in it, but is unfortunately lost. ${ }^{22}$ At least two later reports, however, by Abdülkerim Efendi (1775-76) and Mustafa Râsih Efendi (1793-94), do survive. Abdülkerim's

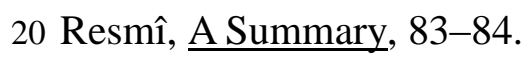

21 Faik Unat, Osmanlı Sefirleri ve Sefaretnameleri (Ankara: Türk Tarih Kurumu, 1992).

22 Mehmed Derviş went twice to Russia. Hâkim includes his first report (1755) in full in his chronicle, MS Bağdat nr. 231, fols. 150a-62b, Topkapı Palace. Abridged in Vâsıf(1804), 1: 61-66. Derviş' second report (1764) seems to be lost. 
report is mostly unhelpful for our purposes, avoiding direct comment on the empress and maintaining an even, cordial tone. ${ }^{23}$ Mustafa Râsih's account offers more explicit opinions. Râsih in fact submitted two reports: an official account detailing his embassy's travels, its arrival in St. Petersburg, and Russia's military, geography, and economic situation, and a memorandum (arîza) with more on the country's economy, internal affairs, and politics. It is this memo that touches most directly on Catherine. ${ }^{24}$

Râsih raises many issues similar to those above. He too hints at Catherine's illegitimacy by placing her within the imperial succession back to Peter I (Deli Petro or "Mad Peter"). As he tells it, she is the latest in a series of empresses nearly all of whom rose to power through questionable means. Peter's niece first seized the throne, he says, Anna I (Anna Ivanovna, d. 1740), deposing the rightful ruler Peter II (Petro Alekseievich, d. 1730) with tricks and deception (i‘mâl-i desâyis ü hiyel ile) to reign for ten years. The child Ivan VI (Ivan Antonovich, d. 1764) succeeded her for only a year before being deposed in turn by another woman, this time Peter's daughter Elizabeth I (Elizaveta Petrovna, d. 1762). This Elizabeth, Râsih writes,

Bir gice. . .da‘vâ-yı mesned-i kıraliyyete kiyâm ve kral ortaları didikleri dört polk 'askerlerinin zâbıtânı ile nihânî mu'âhede ve mukâvele birle def'aten kral sarayına hücûm ve iktihâm ve çar-1 sabiyi ahz ve zindân-bend ve vâlidesi olan Nemceviü’l-asl çariçeyi ve mîr-i kebîr itlâk olunan zevci Antoni hudûd-1 Rusya'dan ihrâc ve Nemçe arâzisine sevk

23 Norman Itzkowitz and Max Mote, trans. and eds., Mubadele: an Ottoman-Russian Exchange of Ambassadors (Chicago: Univ. of Chicago Press, 1970).

24 Both reports in Y1lmaz Karakaya, ed., "Mustafa Rasih Efendi'nin 1793 Tarihli Rusya Sefâretnâmesi," (Master’s thesis, Istanbul Univ., 1996). 
ve ib'âda ihtimâm. . .

One night claimed the throne. She made a secret pact with the officers of the four regiments, known as the imperial guards, and repeatedly attacked the palace. They arrested and imprisoned the child tsar and expelled his mother the Austrian tsarina and her husband, Anthony, called the great lord, from Russia back to Austria. ${ }^{25}$

Râsih likewise deals with Catherine's rise to power in a palace coup. After the Empress Elizabeth's death, he says:

Yeni olan Petro-yı sâlis imparator olub bir sene mikdarı mesned-i kraliyyetde oldığı hengâmda gulüvv-1 'âmm ile binyüz yetmişaltı senesinde mesnedinden cüdâ ve zevcesi olub hâlâ Rusya kıraliçesi olan Katarina-i sânî imparatorluk makâmına geçmekle kâmrevâ olmuşdur kıraliçe-i mesfûre kemâl hırs ve tam‘ında nâş̧i tahrîk ve ifsâdıyla ahâlînin kulûbunu imparator-1 mesfûrdan tebrîd ve tenfîr ve ittifâk-1 ârâ-yı cumhûr ile kendisi makâm-1 kraliyyete nasb ve takrîr eyledikden sonra imparator-1 mesfûr Petraşkof nâm mahallde habs ve tescîn ba'dehu birkaç gün zarfinda mesmûmen îsâl-i derk-i sicîn itmiş oldığ ba'zllarının takrîrlerinden müstebândır

The young Peter III [Petro Feodorovich, d. 1762] became emperor and ruled for a year when he was deposed, in 1762, in a popular uprising. Catherine II, his wife and now Russian queen, obtained her aim by taking the throne. Rebelling out of pure greed, the

25 Karakaya, 111. Reading "sulbiyye" for "salbiyye" and "mîr-i kebîr itlâk" for meper-i kebîr ittilâk." Cf. the nearly identical text in Mehmed Emnî, 71-72. 
said queen turned the people's hearts against the emperor and took the throne by unanimous acclamation. Afterward, the said emperor was imprisoned at the place called Peterhof; we have it on the reports of certain individuals that he then died within a few days by poison. ${ }^{26}$

Nor did the fact that Peter and Catherine had a son stop her from taking power. When the empress had deposed her husband, writes Râsih, Paul was still a child and she became regent. However, "ba“dehu zevci merkûmenin yine kendi sû'-i sanî‘iyle helâkı vâk1' oldukda mersûme Katarina-i sânîyye desîse ve hile ile kalub nâsı tarafına celb. .." [Once her husband died, again by her own machinations, the said Catherine II stayed in power through tricks and deception and garnered popular support.] Râsih says that she named Paul the crown prince and patiently bided her time, ruling as regent, until she could usurp the imperial title for herself. ${ }^{27}$

Mustafa Râsih undercuts Catherine's legitimacy in other ways, as well. The ambassador's memo includes an account of Grigorii Potemkin (d. 1791), for example, Catherine's late favorite, and his influence on the realm. Râsih's views again revolve around Ottoman ideas of the sexeshe argues that Potemkin while alive was the real ruler, the power behind the throne- and remind us too of Western reports, which often claimed that Catherine had ceded her authority to Potemkin. ${ }^{28}$ Yet while Râsih hints that Catherine is illegitimate, and in any case controlled by male advisers and favorites, he at the same time sees female usurpers as an accepted phenomenon in Russia. To this end, Râsih claims implausibly that the crown prince Paul is

26 Ibid, 111.

27 Ibid, 156.

28 Meehan-Waters, 297-300. 
considered insane ( $\underline{\text { mecnûn}})$ and, as such, many courtiers want Paul's wife Maria Feodorovna (d. 1828) to replace him as heir. The empress will soon die; there will then either be great upheaval or Maria will succeed and displace her own children, he says, like Catherine before her. ${ }^{29}$

\section{Catherine and the Pugachev Rebellion}

Like her sex, Ottomans of the day saw Catherine's fundamental legitimacy as a central issue and followed challenges to her rule closely. The Pugachev Rebellion is thus one of few internal Russian events that our sources treat in any detail. Emel'ian Pugachev led an explosive peasant revolt along the Volga in the years 1773-75. A Don Cossack, Pugachev harnessed discontent in the Cossack hosts and, in 1773, assumed the guise of the late Peter III. He gathered a mass of rebels, seized the towns of Samara (1773) and Kazan (1774), and besieged Ufa, Orenburg, and others, until imperial forces under Aleksandr Bibikov and Ivan Mikhel'son put down his rebellion and executed him. ${ }^{30}$ While often inaccurate, Ottoman sources on this event relate directly to Catherine. The accounts dismiss wider social causes and instead make the event a contest over the empress herself, particularly over her fitness to rule.

One Necâtî Efendi left an account of this uprising in his so-called sefâretnâme, actually a captivity narrative. Necâtî fought under the Crimean front commander İbrahim Paşa, with whom he was captured in 1772 and sent as a prisoner-of-war to St. Petersburg. His narrative of the rebellion is frequently muddled and inaccurate, probably based on half-truths and rumours then

29 Karakaya, 151 ff.

30 See John T. Alexander, Emperor of the Cossacks: Pugachev and the Frontier Jacquerie of 1773-1775 (Lawrence, KS: Coronado Press, 1974); and de Madariaga, 239-55. 
circulating in the capital. This Pugachev, or Bugaçor as Necâtî calls him, was a Cossack noble (Kazak tâifesinden bir bey-zâde). Freed from prison in Siberia in 1772, he gathered forty to fifty thousand men and for two and a half years seized many towns and fortresses near Moscow, the Volga, and Kazan. Eventually, Necâtî says, the Russians sent an army under General Bibikov (Bibek) - a force that he claims Pugachev met and destroyed—followed by a second failed expedition. We are told Pugachev then not only took the city of Kazan but threatened Moscow and marched on Astrakhan (Ejderhan $).{ }^{31}$

Necâtî argues that popular anger with Catherine's rule helped to fuel the uprising and that even the citizens of Moscow, from the governor and generals to soldiers and subjects, conspired to surrender the city to the rebels. The nobility were called "sweepers (ennâs)," he says. They were upset with the empress, saying, "Fürû-mâyeden kimesneye i'tibâr eder bizlere i'tibâr yokdur." [She respects anyone who is lowborn but has no respect for us!] These sentiments in time spread to St. Petersburg, where, one day, a letter from Pugachev to Catherine appeared on the palace gate. It read:

Ben ki senin zevcin kral Petro’yum ben kral iken devletim ile bir olub ve 'askerim Brandebol cenglerinde iken ber-takrîb Petrohof nâm bağçede ahz ve habs ve yerime kraliçe oldun ki oğlum sagîr ve sabîdir büyüdükde oğlum kraldur deyü bu gûne tezvîrât ile beni katl murâd eylediğinde benim yerime âharı katl olundu ve bana müşâbih olmak

31 Erhan Afyoncu, ed., "Târih-i Kırım (Rusya Sefaretnâmesi)” (Master’s thesis, Marmara Univ., 1990), 39-41. See also Unat, Osmanlı Sefirleri, 116-28; and idem, "Kırımın Osmanlı idaresinden çıktığı günlere ait bir vesika: Necati Efendi Sefaretnâme veya Sergüzeştnâmesi,” Türk Tarih Kurumu Kongresi 3 (1943): 367-74. 
hasebiyle beni halâs itdiler ve ben on yedi senedir ki gezerim şimdi geldim ben eski tahtgâhım olan Rusya'da sâkin olurum sen dahî oğlumu kral idüb bir kilisede sâkin olasın ve illâ kendisi helâk bilesin

I am your husband, King Peter! I was at one with my realm as king but, while my army was at war with Brandenburg, I was seized and imprisoned by some means in the garden called Peterhof. You became queen in my place with sophistries that my son was a child and that, when he grew, he would be king. When you wished to murder me, however, another was killed in my place. This man resembled me and so they set me free. I have wandered for seventeen years and have now returned. I shall reside in Russia, my old kingdom. You shall make my son king and retire to a church, otherwise know that you are doomed. $^{32}$

This "letter" appears to be wholly fabricated but correctly identifies Pugachev as a pretender, the dead Peter III. In transcribing it, Necâtî shows that he grasps the corrosive power of this pretense on Catherine's right to rule.

Necâtî also paints Pugachev as friendly to the Ottomans, writing his own empire into the story on the basis of Tatar sources and rumors. He claims the rebel promised to deliver the Kazan Tatars over to the realm of Islam (sizleri diyâr-1 islâma çıkarub halâs iderim) if they helped him. Likewise, he says that Pugachev sent envoys to the Ottomans after he captured "Sudurmu (Samara?)." Pugachev in this message asked the imperial army to be at the ready: "Sâbıkâ Moskov kralı Deli Petro yirmi iki târihinde Şived kralını nice Osmanlı toprağına sürüb çıkardı

32 Afyoncu, 40-41. 
ise inşallâhu te'âlâ ben dahî bu kraliçeyi öyle iderim murâdım Devlet-i ‘Aliyye’ye hizmeddir ma'lûmları ola..." [Let them know that, just as the old Muscovite king Peter drove the Swedish king into Ottoman realms in 1710, so God willing shall I treat this queen. My aim is to serve the Ottoman Empire. $]^{33}$ These anecdotes seem above all to be products of wishful thinking-we have no indication that they are true. Necâtî links Pugachev in a similar way to the fortunes of his homeland and its war with Catherine. This was such a great rebellion, he writes, that had the empire held out for only a few more months, they would likely have beaten the Russians. ${ }^{34}$ Interestingly, Necâtî denies Pugachev's capture and execution—a well-documented and brutal event (Pugachev was beheaded, drawn, and quartered). He instead says the rebel died at the hands of two escaped criminals who joined him on the way to Astrakhan. These men killed Pugachev with the help of other disaffected officers and in time brought the corpse to Moscow, where it was publicly burned. Necâtî says that Ottoman captives saw this occur but hesitated to pass on the information, for it would have demoralized their peers. He then adds: "lâkin mesfûr Bugaçor'un ele girmesinin aslı yok idi.” [But there is no truth whatsoever in Pugachev's capture. $]^{35}$

Sadullah Enverî and Ahmed Vâsıf offered slightly different takes on the rebellion in their chronicles. These, too, though, put Catherine and her legitimacy at the heart of matters. Enverî writes that the uprising stemmed from Catherine's misrule, especially her treatment of the

33 Ayfoncu, 40. There may be an echo here of Pugachev's reported plans (de Madariaga, 24142) to lead his men into the Ottoman Empire.

34 Ibid, 41.

35 Ibid, 43. 
Cossacks. The trouble began when the empress exceeded all equity (hadd-i i'tidâli tecâvüz ve

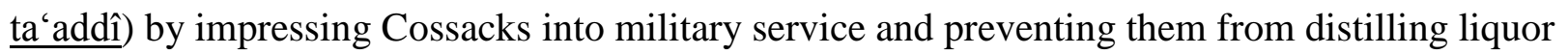
('arak, presumably vodka). Catherine also imprisoned some of their chiefs, says Enverî. The rebels then captured a place called Orenberg (Durinburg) with their leader Pugachev, here called

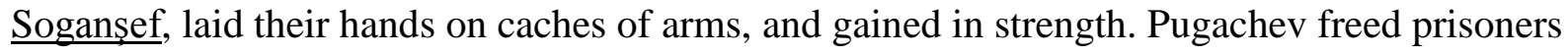
and gathered an army of some forty thousand men; he set off for Moscow, routing the generals sent against him by Catherine. ${ }^{36}$ It was only at this point that the empress took the uprising seriously, Enverî writes, dispatching an army and offering a reward of 360 piasters for his head. ${ }^{37}$ The situation by then had become critical, however. Enverî stresses that these events stoked a full-scale crisis in Catherine's legitimacy, as Pugachev's followers began to gather support, kill their opponents, and question the empress' very right to the throne:

Mesfûr Soganşef ise fi'l-asl Petreburk’da ba‘zı tarafgîrler peydâ itmiş olmağla mersûme Katerine'nin imparatoriçeliğin gasben tahsîl eylediğin iddi'â ve imparatoriçeliği sahîh olmadığın da ‘vâ idüb imparatorluk irsen mesfûrenin oğlı Granduka’nın olmağla ana teb“iyyeti izhâr ve belki imparator itmek sevdâlarında oldığın âşikâr eyleyüb

As for Pugachev, he had initially won some partisans in St. Petersburg. These claimed that the said Catherine had seized the throne by force and that her rule was dubious. As the throne belonged by inheritance to her son the Grand Duke, they declared loyalty to

36 Çalışkan, 456.

37 Ibid, 456-57. 
him and even made it clear that they wished to make him emperor. ${ }^{38}$

Basing his account partly on Enverî, Vâsıf generalizes Catherine's misrule from specific attacks on the Cossacks into sheer injustice (zulm). Much of his emphasis remains the same, though. After the empress' coup, Vâsıf writes, she enjoyed good fortune in wars with Austria and Prussia and thereby gained the submission and devotion of her people. ${ }^{39}$ However, a Cossack named Pugachev ( $\underline{\text { Soganșef }}$ ) arose and vowed to defend the peasants from the empress' tyranny

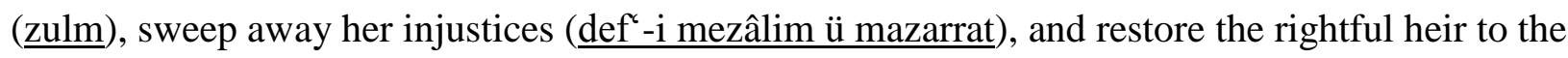
throne. ${ }^{40}$ Pugachev captured Orenberg, seized a great many weapons and arms, and destroyed his opponents. He freed prisoners in the jails and, spreading propaganda, gathered a great mass of troops. While this situation pleased the late emperor's partisans, Vâsıf says, the Orlovs' fortitude stopped the rebellion from spreading; after throwing Russia into a great upheaval, Pugachev and most of his followers died at the hands of the empress' agents. Like Necâtî, Vâsıf ends his account by briefly pausing on the rebellion's ripples in Ottoman lands. Word that this unprecedented rebellion had reached its end gained notoriety in the imperial army, he writes, but while many learned men hoped for the empress' downfall, they were disappointed. She survived a long while and continued to plague the empire and other powers. Vâsıf then concludes with an Arabic verse: "Inna al-kilāb țawīlat al-a 'mār.” [Dogs are indeed long-lived.] ${ }^{41}$

38 Ibid, 457.

39 Vâsif (1804), 2: 287.

40 Ibid, 2: 287.

41 Vâsıf (1804), 2: 286-87, reads al-kalām (“words”). Cf. idem, MS nr. 5972, fol. 226b, Istanbul Univ. Library. 


\section{Tyrant and Divine Trial: an Empress Vilified}

What underlay Ottoman hostility toward Catherine? How much of our sources' animus comes from misogyny, for instance? We might begin to form an answer to this question by looking at how Ottomans viewed other female rulers, including earlier eighteenth-century Russian empresses. All told, I do not think the hostility of contemporary accounts is entirely or even mostly due to Catherine's status as a female ruler. Misogyny was present whenever Ottomans encountered female rulers, to be sure. The empire did not know quite how to treat the Russian empresses of the early 1700s, for example. In 1740, Sultan Mahmûd I sent one Mehmed Emnî as his ambassador to St. Petersburg following the Treaty of Belgrade. But he decided that it was improper to invite Emnî to the palace before his departure — as protocol dictated—because the reigning Russian monarch, Anna, was a woman. The sultan had the Grand Vizier receive Emnî instead. $^{42}$

Mehmed Derviş voiced similar ambivalence during his stay at the court of Elizabeth I. While there, the empress invited him to a masquerade ball (nikâb gicesi), an event that, try as he might, he could not avoid. Derviş describes the ball with seeming disapproval. Men and women mixed together, held hands, and danced, he says, all with faces veiled, while the empress herself joined the dancing. He adds that Elizabeth later ordered her servants to take him on a tour of her quarters - surely a shock for well-bred Ottomans, who strictly excluded outsiders from the

42 Mehmed Subhî, Subhî Tarihi: Sâmî ve Şâkir Tarihleri ile Birlikte 1730-1744, ed. Mesut Aydıner (Istanbul: Kitabevi, 2007), 624. See above on Emnî’s report. 
private area of their homes ( $\underline{\text { harem })} .{ }^{43}$ Necâtî offers a parallel story, too, a court masquerade, focusing especially on the element of cross-dressing-Catherine dressed as a man, we are told, while her ministers Panin and Orlov came as Algerians. ${ }^{44}$ In both cases, however, Mehmed Derviş and Necâtî, there is discomfort but not outright hostility.

Nor do we see overt hostility in Ahmed Resmî's 1757-58 report from the court of Maria Theresa. Resmî knew that sovereign's personal history and accurately describes the events around the Pragmatic Sanction, her accession to the Habsburg throne, and the War of Austrian Succession. He writes that, as a woman, Maria Theresa was ineligible to succeed her father Charles VI as Holy Roman Emperor and that some of the imperial electors refused to recognize her. It was only after several years, at the death of emperor Charles VII, that she was able to secure the imperial title for her husband Francis. Resmî adds that Francis became "titular (lafzî)" Holy Roman Emperor, however, recognizing Maria as the stronger partner in the marriage. He treats these events in straightforward, factual terms. Resmî may well have felt somewhat reassured (as did other European observers) by Maria's domestic image and the fact that she ruled with her husband and not alone. ${ }^{45}$

Rather than simple misogyny, I suggest that Ottoman vilification of Catherine stemmed from two larger, related issues. First, Ottoman contemporaries did not accept the empress as legitimate. The circumstances of her rise to power were deplorable by their standards. She was a

43 Hâkim, MS Bağdat nr. 231, fols. 156b-57b.

44 Afyoncu, 36.

45 Ahmed Resmî, Viyâna Sefâretnâmesi (Istanbul, Ebüzziyâ, 1887), 25-26. See also MeehanWaters on Catherine's contrast with Maria Theresa, 300. 
woman, of course, but also an interloper, usurper, and regicide. We have seen that Ottoman accounts stress Catherine's foreign origins. She was not "of the blood"- a prerequisite in the Ottoman dynasty, which boasted centuries of unbroken rule and strictly controlled royal reproduction and succession. ${ }^{46}$ For Ottomans, the fact that Catherine was a foreign usurper must have been nearly as bad as her status as a female usurper. The latter, it is true, was also a black mark. Catherine - a German interloper — had overthrown and likely murdered her husband and then sidestepped her own son's rights to the throne. To Ottoman minds, she had deliberately subverted the "normal" order of the home, of the realm, and of her society at large. By their benchmarks, this meant that Catherine was an abnormal, unnatural, thoroughly depraved ruler.

The vocabulary that our sources use to discuss Catherine and her rule strengthens this argument, linking her to Ottoman discourses on illegitimacy, injustice, and tyranny. Ahmed Vâsıf explicitly refers to the empress' injustice ( $\underline{\text { zulm })}$, for example, a term with a long history in Islamic ethical and political thought and origins in the Quran. Literally meaning "putting a thing in a place not its own," zulm implies a transgression of moral limits and an encroachment on the rights of others, God or man. ${ }^{47}$ In the Ottoman period, as well as other eras of Islamic history, it also had the political meaning of evil, wrongdoing, oppression, and tyranny. It was the opposite

46 Peirce, esp. 15-27. While all non-Muslim rulers were, in theory, illegitimate, the Ottomans in practice usually recognized the established houses of Europe. The rhetoric toward Catherine differs markedly from that used toward her contemporaries.

47 Vâsıf (1804), 2: 287. See too Bernard Lewis, The Political Language of Islam (Chicago: Univ. of Chicago Press, 1988), 91-116, 155 n. 30; and H.A.R. Gibb et al, eds., Encyclopaedia of Islam (EI²), 2nd edition, (Leiden: Brill, 1960-2006), s.v. “Zulm.” 
of 'adl — a putting a thing in its rightful place - i.e. justice in either personal ethics or political morality. Vâsıf also qualifies Catherine's actions with words from the same root as zulm

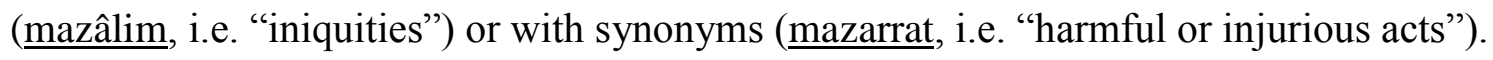
Sadullah Enverî made much the same point in calling Catherine’s deeds "untoward (mu'âlemât-1 nâbercâsı)" and saying that they "exceeded all equity (hadd-i i'tidâli tecâvüz ve ta'addî)."48

Our sources are equally clear toward Catherine's seizure of power. Enverî says that Catherine took the throne "by force (gasben)," a word that in general means taking something forcibly but is also a specific legal term for usurpation: "high-handed appropriation," i.e. "the unlawful appropriation of something belonging to another or the unlawful use of the rights of another." Enverî uses the same word and synonyms elsewhere for Catherine's confiscation of her subjects' property. ${ }^{49}$ Vâsıf adds to this picture by repeating that the empress "seized control of Muscovy by force (kendüsi tagallüben Moskov memâlikini istimlâk)." Here he again connects Catherine to Ottoman ideas of illegitimacy with the keyword tagallüb, meaning superior force or power. While not a legal term like gasb, this word had strong connotations of illegal seizure, tyranny, and oppression. Catherine rose to power through usurpation, he implies, by taking the throne wrongfully rather than by legitimate means. ${ }^{50}$

48 Çalışkan, 456.

49 Çalışkan, 456. See also EI², s.v. "Ghașb."

50 Vâsıf, MS nr. 5979, fol. 147a, Istanbul Univ. Library. Cf. Franciscus Meninski, Thesaurus Linguarum Orientalium Turcicae-Arabicae-Persicae (Vienna, 1680), 1: 1271-272, for the usage tagallüb tarîk ile: "Praevalentibus viribus, per praepotentiam aut tyrannidem ac oppressionem debilioris. Per la prepotenza, per tirannia ò oppressione." 
The second issue is that Ottoman observers judged Catherine in the wider context of their empire's conflict with Russia. Eighteenth-century Ottomans saw Russia's drive south as part of a long-term, conscious strategy by its rulers to extend their realm, contest Ottoman control of the Black Sea, and become a major regional power. Catherine was highly successful in these aims. The Ottomans resented her victories and bristled at her gains, which included parts of the Black Sea littoral and the Crimean peninsula itself. It was the last that mattered most: ruled by the Crimean Khans till the Russian annexation of 1783, the Crimea had been an Ottoman vassal state for three centuries and a largely Tatar, Muslim territory. Its loss was a blow to Ottoman statesmen, forcing them to reflect on what had gone wrong. ${ }^{51}$ To some extent, Catherine came personally to embody this struggle and to serve as a vessel for deeper Ottoman fears. How had they been beaten? How had they been beaten by backward infidels led by a woman? Our sources' concern is not just about Catherine as an individual, then. It is about her larger meaning for Ottoman officials: for what, they felt, her success signified for the empire and its long-term fortunes.

According to Ahmed Resmî, for example, Russia's rise stemmed from a desire to rival the other states of Europe. The Ottomans had conceded the tsars an imperial title in the 1739 Treaty of Belgrade, he writes, but at first the Russians only equaled France, Austria, and Spain in title. "Thinking to rival them also in arms and majesty," he continues, they embarked on a thirty-year program.

They drilled many soldiers, acquired galleons and practical light artillery for their war ordnance, and during the year 1761 sent troops into Prussia to aid the Austrians. The

51 See Aksan, Ottoman Statesman, 171-84; and Menchinger, 63 ff. 
Russians won a fame and renown greater than before through their total victory over Prussia; amidst peers they exercised imperial rule. Thereafter, they preserved the order of this arrangement - they took pains to augment and strengthen it day by day. ${ }^{52}$

Resmî credits the Russians' newfound power to the tactics they learned from the Prussians in the War of Austrian Succession (1740-48) and Seven Years' War (1756-63). Still, Resmî contends that they were not initially interested in the Ottoman Empire. The conflict between them stemmed from two immediate issues. First, Resmî blames the Tatars for provoking the Russians - they had harassed the Russians for centuries, he says, and goaded them to attack the Crimea. Second, the Russians had now overextended themselves and needed territory to "pasture their army," which they found in Poland, an Ottoman neighbor. ${ }^{53}$

Ahmed Vâsif also felt that Russian expansion was a deliberate and sinister program. As he writes in his chronicle, the Russians had been in a state of renewal for nearly a century, ordering their realm, reforming their military, and testing the fruits of their labor in several successful wars. ${ }^{54}$ For Vâsif, the Russians in part followed geographical imperatives. Their realm was cold and barren and the territories they had newly conquered were in the far north, so that any agricultural output from them proved middling, "less than a trifle (ednâ min fetîl)." The Russians thus schemed to gain more advantage and commercial profit, coveting the rich, strategic lands of Poland and Crimea. ${ }^{55}$

52 Resmî, A Summary, 82-83.

53 Ibid, 34-35.

54 Vâsıf (1804), 2: 4.

55 Vâsıf (1804), 2: 4-5. See also Vâsıf, MS nr. 5978, fols. 97a, Istanbul Univ. Library. 
Yet Vâsif also alleges that the Russians acted, at least in part, according to a secret plan: the "epistle" of Peter I (Deli Petro risâlesi). He writes:

Tâife-i Rus Deli Petro risâlesinde temhîd olunan mukaddemât-1 fâsideyi refte refte icrâ idüb risâlenin 'illet-i gâ‘iyyesi olan Kırım ülkesini tergîb ü terhîb sûretinde teshîr ve beyne'd-düvel cârî olduğı gibi ibtidâ-yı emirde serbestlik 'unvânıyla ahâlîyi tevkîr ve giderek zabt vesâilini tedbîr itmek garazlarını teysîre başladılar

The Russians slowly executed the perverse premises set forth in Peter I's epistle. They began to accomplish their goal of conquering the Crimea - the ultimate aim of the epistle - through provocation and menace, first honoring its inhabitants with the title of "freedom" now in vogue among the states and in time arranging the pretexts to annex it. ${ }^{56}$ Vâsif's words may be an early reference to the spurious "Testament of Peter the Great," which became notorious in the nineteenth century. Article Eight of this document urges Russian rulers to "extend our frontiers. . .southward along the shores of the Black Sea," while Article Nine calls on them to "establish wharves and docks on the Black Sea and by degrees make ourselves master of that sea." Whether or not he knew of the so-called "testament," Vâsıf had clearly heard similar ideas about Russian ambitions and adopted a conspiratorial view. ${ }^{57}$

56 Vâsif (1804), 2: 176-77.

57 Translated in Dimitry Lehovich, "The Testament of Peter the Great," The American Slavic and East European Review 7 (1948): 112. See Turkish and French versions in Rusya İmparatorı Birinci Petro'nun Vasiyetnâmesi ile Pâris'de ‘Akd olunmuș olan 'Ahdnâme (Istanbul, 1870/71). Orest Subtelny has shown that, while the "testament" first appeared in 
What troubled contemporaries most was neither Russia's rise nor its ambitions, though. Ottomans wished to understand Catherine's success - the basis of her victories over them and the crux of their worry and puzzlement. The early modern Ottoman elite based its worldview on a sort of political exceptionalism. The empire, they held, had been divinely supported and blessed by God since birth. Its rapid expansion and conquest of Constantinople proved as much, while numerous prophecies predicted that the Ottoman dynasty and its rule would last literally until the end of time. Many Ottomans evidently believed that, come what may, their empire was invincible. It followed, then, that explaining Catherine's triumphs and their own losses was an issue of the highest psychological magnitude. How was it that this infidel Russian empress could defeat their "eternal empire"? ${ }^{58}$

Our sources nearly all interpret Catherine's victories as divinely ordained. What is more, they imply that Russian ascendancy will only last as long as the empress lives. The sources often use the same word, istidrâc, a term that we might loosely translate as "divine trial." İstidrâc occurs when God grants a sinner temporary success in this world, in order to lead him or her by degrees to damnation and test the fidelity of believers. ${ }^{59}$ Catherine was endowed with this power, the sources say. Râsih writes that Catherine was able to seize the throne by waiting for an opportune moment; the other European powers recognized her as empress and, "te'sîr-i tâli'i

print in 1812 in France, stories of Peter I's plans for European domination circulated in Europe from the early 1700s onward: "Peter I's Testament: a Reassessment," $\underline{\text { Slavic Review }}$ 33 (1974): 663-78.

58 Menchinger, 28-30.

59 Menchinger, 96. See also Şemseddin Sâmî, Kâmûs-1 Türkî, (Istanbul: A. Cevdet, 1900), 98. 
hasebiyle husûs-1 istidrâcı kuvvet bulmuşdur.” [Her istidrâc gained in strength due to the effects of her good fortune. ${ }^{60}$ Necâtî argues that God himself preserved the empress from the Pugachev Rebellion, consoling his readers that "Levh-i takdîrde mukadderât-1 ilâhî gelür hep zuhûr eyler fehvâsınca inşallâhu te‘âlâ murâd üzere ahz-1 intikâm olunur.’[We will have our revenge as God wills, following the saying, 'What God wills in the Tablet of Fate shall come to pass and all shall be clear.'] ${ }^{61}$ As for Halil Nûrî, he also ties Catherine's fortunes to the divine, attributing her success to God's hidden wisdom. ${ }^{62}$

Ahmed Resmî and Ahmed Vâsıf both argued that Catherine benefited from istidrâc, citing many examples. In his history, Resmî says that "Catherine was aided by fortune and swam on a

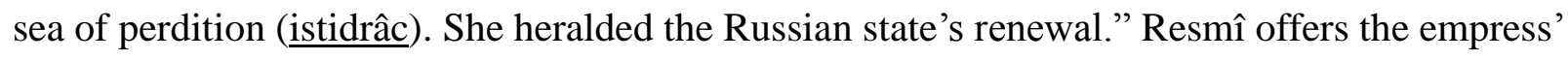
victories on the Mediterranean in the $1768-74$ war as a concrete instance of her powers:

While experienced men would predict that they were a bunch of novice, rash infidels on Mediterranean Sea waters, and that it was certain they would be imperilled and dispersed by one good storm, by decree of fate ( $\underline{\text { bi-hükm-i istidrâc) }}$ the winds favored the Russians in all ways. In their first attack, they bottled up our fleet at the place called Çeşme, opposite Chios, and routed it. ${ }^{63}$

Resmî presented similar points in an essay that he wrote in the year 1772. Here he again refers to

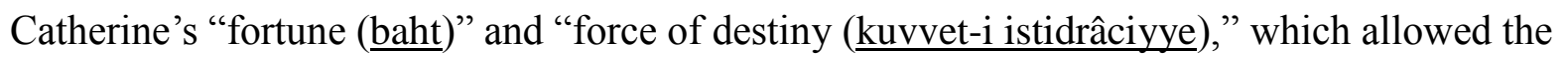

60 Râsih, 156.

61 Afyoncu, 41, reading "ahz-1 intikâm” for “ahz-1 intizâm.”

62 Nûrî, fol. $257 b$.

63 Resmî, A Summary, 84-85. 
Russians to occupy parts of the empire. ${ }^{64}$ For his part, Vâsıf uses the notion of divine trial throughout his work to explain the empress' victories against Austria and Prussia, her survival against Pugachev, her acquisition of the Crimea, and her ability to win concessions from the Ottomans. Vâsıf also credits much of Catherine's military success—and Ottoman military failure - to istidrâc. "Even if our men now face reverses and the infidel sometimes prevails on land or sea," he writes, "this is merely a result of istidrâc, born from their satanic efforts."

For Vâsıf and others, though, God's favor was not meant to help the Russians in the long run nor was it to last. İstidrâc is temporary, Vâsıf notes in his chronicle. It is absurd (müstahîl) to think it can last forever and in the end, he contends, God will restore the Ottomans to favor and success. ${ }^{66}$ Resmî, too, focuses on the temporary nature of Catherine's fortune. It is the greatest of prodigies (bu makûle nâdire hâdise-i kübradır), he writes, something which so defies the natural conditions of the world that it can only occur once in several centuries. ${ }^{67}$ Resmî likens the empress' success to a force of nature, violent and destructive but fleeting. It is a "freak of nature (galat-1 tabî‘at)," he says, an aberration like a flood (seyl suyu) or hurricane (tûfân didikleri biyük firtına); the monarch's ascendancy is "a tempest" (riyâh-1 ședîd ile muhtelit bir sâ'ika)

64 İsmet Parmaksızoğlu, "Bir Türk Diplomatının Onsekizinci Yüzyıl Sonunda Devletler Arası İlişkilere Dair Görüşleri,” Belleten 47 (1983): insert, pp. 42, 48.

65 Quoted in Menchinger, 96. See also, for example, Vâsıf (1804), 2: 4, 157, 245-46, 287-88; idem, MS nr. 1406, fols. 94a, Topkapı Palace; and idem, ed. Mücteba İlgürel (Ankara: Türk Tarih Kurumu, 1994), 12, 14, 53.

66 Vâsıf (1994), 151. See also Menchinger, 96-97.

67 Resmî, A Summary, 85. 


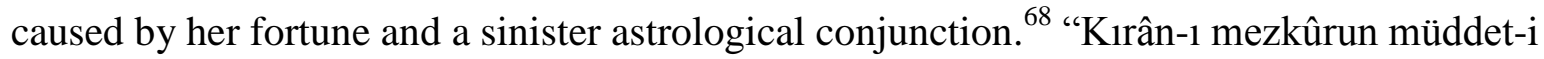
inkızâsı,” Resmî concludes, “veya sâhib-i kevkebenin zevâl u intifâsıyla zâ’il ve münkazî olageldiği tecrübe ile ma "lûmdur." [We know by experience that it shall subside with the end of the said conjunction and the decline of her star. $]^{69}$

\section{Conclusion}

We might excuse Ottoman observers for their optimism if they predicted a swift Russian eclipse on Catherine's death. Halil Nûrî celebrated the 1796 event in his chronicle, saying it augured well as a sign of Russian disgrace and abasement. ${ }^{70}$ Vâsif, too, was overconfident. After Catherine died, he writes, "Rusyalu'nun bahtı bergeşte ve zicâc-pâre-i sevretler şikeste oldı." [The Russians' fortunes turned and the spearheads of their power were broken.] ${ }^{71}$ Ottoman elites no doubt hoped that Paul I's succession to the Russian throne would right the balance of their rivalry, just as systematic military reform, begun, incidentally, as a direct result of the late empress' victories, would restore Ottoman arms to their old glory. The Catherine of the Ottoman imagination had passed - Catherine the usurper, the hag, the regicide, the force of nature, the scourge of God - and now she burned in hell. Why shouldn't Ottoman fortunes improve?

Of course, these hopes did not materialize. The Ottoman Empire would fight four more

68 Parmaksızoğlu, insert p. 48; and Resmî, A Summary, 84-86. Resmî in part blamed a conjunction of Mars and Saturn in the constellation of Cancer.

69 Parmaksızoğlu, insert p. 48.

70 Nûrî, fol. 257b.

71 Vâsıf(1804), 2: 288. 
wars against Russia during the nineteenth century, almost all on the losing side, a long-term trend that stemmed from issues like military obsolescence, abortive reform, and bureaucratic inertia more than any one personality. The point here is that, for Ottomans, the struggle to make sense of Catherine was a struggle for deeper understanding. Catherine came to embody the two empires' conflict and its vagaries. At stake was much more than her sex or status as a female ruler. In short, Catherine became a stand-in for Ottoman fears, which crystallized in her person more than any foreign ruler of whom I am aware — she became a touchstone for Ottoman anxieties about the empire's eroding power and waning strength in the world, the prospect of its "decline," and its increasingly uncertain future. 